\title{
Value of gel filtration on Sephadex G-200 in the analysis of blood group antibodies
}

\author{
F. STRATTON, D. S. SMITH, AND V. I. RAWLINSON \\ From the Regional Blood Transfusion Service, Roby Street, Manchester
}

SYNOPSIS Analysis of blood group antibodies on Sephadex G-200 columns is described.

The position of blood group antibodies when whole serum containing them is subjected to gel $\frac{\text { in }}{\sigma}$ filtration is studied and compared with the position of the $\gamma$-globulins and of standard blood group antibodies.

The technique on its own cannot be used to identify the immunoglobulin nature of the antibody음 but is very useful when employed in conjunction with the antiglobulin test using specific antiseraand with other methods.

The technique is rapid, simple, and reliable.

A great deal of work has been done in recent years to try to determine the immunoglobulin nature of blood group antibodies. Examples have been found which belong to all three immunoglobulin classes, although an antibody of a particular specificity may be composed of one, two, or all three immunoglobulin types in the same serum.

In experimental studies of all kinds on blood group antibodies, it is often of value to know the immunoglobulin type of the antibody involved, and the knowledge is of great importance where an atypical antibody is present in a maternal serum, in order to be able to forecast whether it is likely to be transferred across the placenta and give rise to haemolytic disease of the newborn.

A number of methods have been evolved for determining the immunoglobulin type of the antibodies and these include studies of the eluted and purified antibody which have been largely concerned with analyses of 19S $\gamma \mathrm{M}$ globulin (Mehrotra, 1960; Mehrotra and Charlwood, 1960). Kochwa and Rosenfield (1964) have also made studies of purified anti-Rh antibody. The drawback to this approach is that the amount of protein available for analysis is extremely small. Other investigations use serological methods; in these, red cells sensitized with antibody are tested with specific antiglobulin sera thus enabling the immunoglobulin class of the antibody coating the red cell to be determined. This is the most direct method but it has certain limitations and does not always give unequivocal results.

Received for publication 20 February 1968.
Separative methods are more widely used, $\frac{\vec{\varphi}}{\mathscr{\theta}}$ however, either in combination with gel diffusion ${ }_{\infty}$ and immunoelectrophoretic techniques, or with specific antisera in the indirect antiglobulin test. Using these techniques immunoglobulins are separated from whole serum containing the antibody and tested for antibody activity, and by this means $\frac{0}{\circ}$ it is possible to correlate the occurrence of antibody $\circ$ with a particular immunoglobulin type. Separation $\vec{O}$ by DEAE-cellulose chromatography has been 3 most often used (Abelson and Rawson, 1961; Adinolf, Mollison, Polley, and Rose, 1966) and we have found it most valuable. In 1963, Killander and Högman described the use of gel filtration on Sephadex G-200 for the study of blood group 3 antibodies and the object of this paper is to describe further results with this material and to demonstrate the value of the technique in this work.

\section{MATERIALS AND METHODS}

GEL FILTRATION ON SEPHADEX G-200 Gel filtration was performed on Sephadex G-200 (A. B. Pharmacia, Uppsala, Sweden). Serum samples, $1.5 \mathrm{ml}$, were applied 0 to a $2 \cdot 5-\mathrm{cm}$ diameter by $40-\mathrm{cm}$ column containing $\underset{\mathrm{W}}{\mathrm{W}}$ Sephadex G-200, equilibrated with a buffer consisting of $O$ $0.14 \mathrm{M} \mathrm{NaCl}$ in $0.035 \mathrm{M} \mathrm{Na} 2 \mathrm{HPO}$ and $0.006 \mathrm{M} \mathrm{NaH}_{2} \mathrm{PO}_{4}$, pH 7.3. Fractions, each of $2.5 \mathrm{ml}$, were collected at a flow

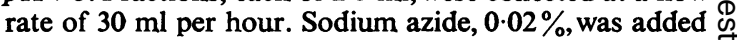
to the buffer to prevent bacterial growth. The protein content of the effluent was recorded automatically as UV transmission at $280 \mathrm{~m} \mu$ in a Uvicord absorptiometer $\frac{\mathbb{D}}{D}$ (LKB Produktor, Stockholm, Sweden).

The effluent fractions were concentrated by ultra- $\stackrel{\mathbb{Q}}{\complement}$ filtration in collodion bags and the immunoglobulin 
levels determined by a single radial diffusion (immunoplate) technique (Fahey and McKelvey, 1965). The goat antisera specific for human $\gamma \mathrm{G}, \gamma \mathrm{A}$, and $\gamma \mathrm{M}$ used in this method were obtained from Hyland Laboratories, Los Angeles, USA, and stored at $4^{\circ} \mathrm{C}$. The $\gamma \mathrm{G}$ and $\gamma \mathrm{M}$ levels were also estimated by the inhibition of antiglobulin serum method.

SEROLOGICAL METHODS Standard serological methods were used as previously described (Stratton and Renton, 1958), and the use of specific antiglobulin sera in the antiglobulin test has also been described (Stratton, Gunson, and Rawlinson, 1962).

TESTING OF CHROMATOGRAPHIC FRACTIONS These were adjusted to $\mu=0 \cdot 15$ and tested without furtheralteration. In the antiglobulin technique $4 \mathrm{vol}$ of fraction or diluted fraction was added to 1 vol of $10 \%$ red cells.

\section{RESULTS}

ANALYSIS OF WHOLE SERUM Figure 1 shows the levels of immunoglobulins found in each of the fractions from the Sephadex column using the standard methods which we employ. It will be seen that the $\gamma \mathrm{M}$ occurs largely under the first peak and the $\gamma \mathbf{G}$ under the second peak, with $\gamma \mathrm{A}$ globulin lying in between. About $5 \%$ of the total $\gamma \mathrm{G}$ globulin occurs in the peak tube using this technique.

ANALYSIS OF ANTIBODIES OF KNOWN TYPE In order to test the method, antibodies of known type (subsequently used as markers in certain investigations) were employed. A 19S $\gamma \mathrm{M}$ anti-I antibody was used either as whole serum or more often as purified and concentrated eluate prepared from red cells. High-titre incomplete anti-D 7S $\gamma \mathrm{G}$ antibody was also used and these antibodies in the form of whole serum or eluates, mixed with the whole serum under test, can be put on the column together, and the result obtained is shown in Figure 2. It will be seen that the anti-I antibody closely follows the pattern of $\gamma \mathrm{M}$ globulin in Fig. 1, and the anti-D,
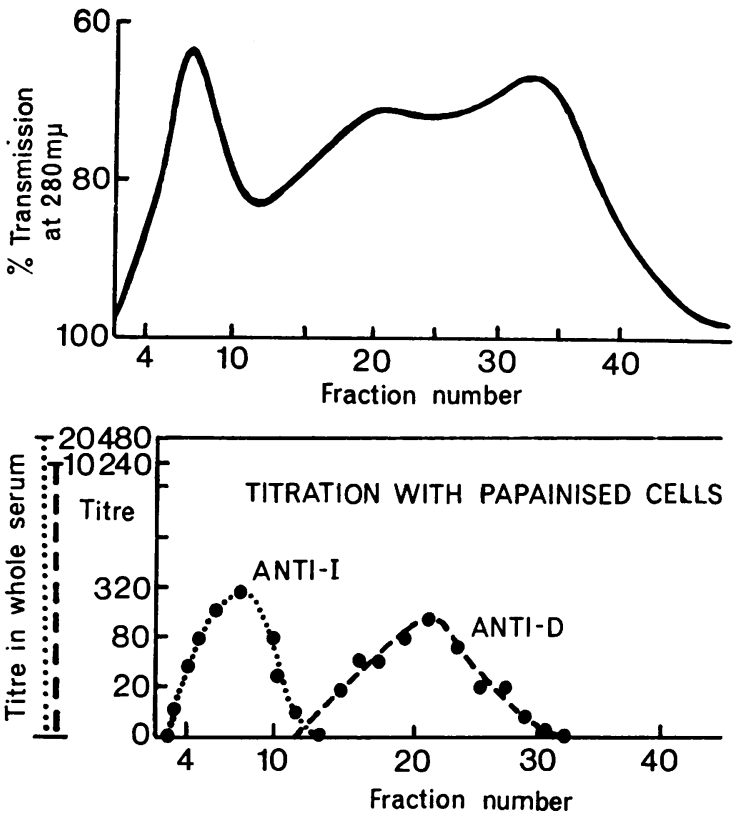

FIG. 2. Gel filtration of normal serum with added markers, anti-D $(\gamma G)$ and anti-I $(\gamma M)$.

the pattern of $\gamma \mathrm{G}$ globulin. There is a clear distinction in the tubes from the column between these two kinds of antibody.

The position of $\gamma \mathrm{A}$ globulin on the column is not always easy to define but Fig. 3 shows an analysis using the antiglobulin test of fractions obtained by passing through the column the serum from a group $\mathrm{O}$ individual (Mr G.) who had received some group A blood. Again, the $\gamma \mathrm{M}$ position of the complementfixing anti-A antibody and the $\gamma \mathrm{G}$ anti-A antibody is clearly seen. The $\gamma \mathrm{A}$ anti-A lies maximally in the trough between the $\gamma \mathrm{M}$ and $\gamma \mathrm{G}$ peaks but does not correspond exactly to the position of the $\gamma \mathrm{A}$ globulin seen in Figure 1.

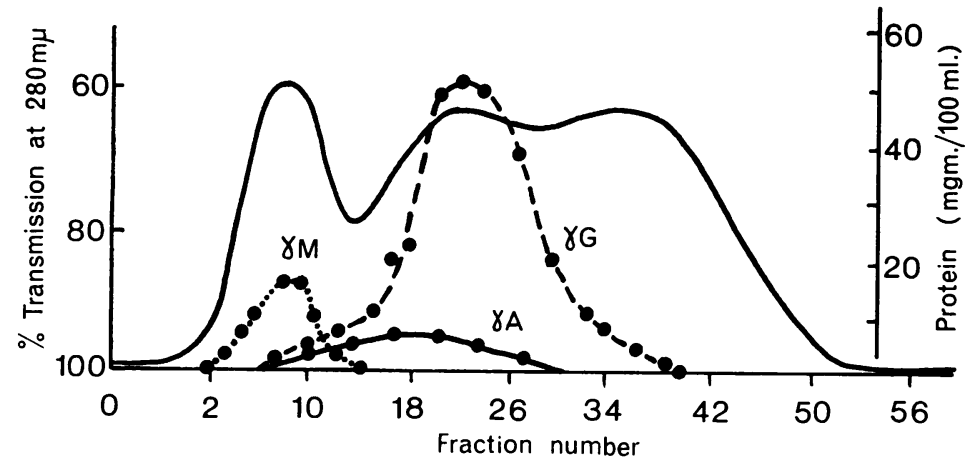

FIG. 1. Gel filtration of normal serum on Sephadex G-200 showing immunoglobulin levels. 

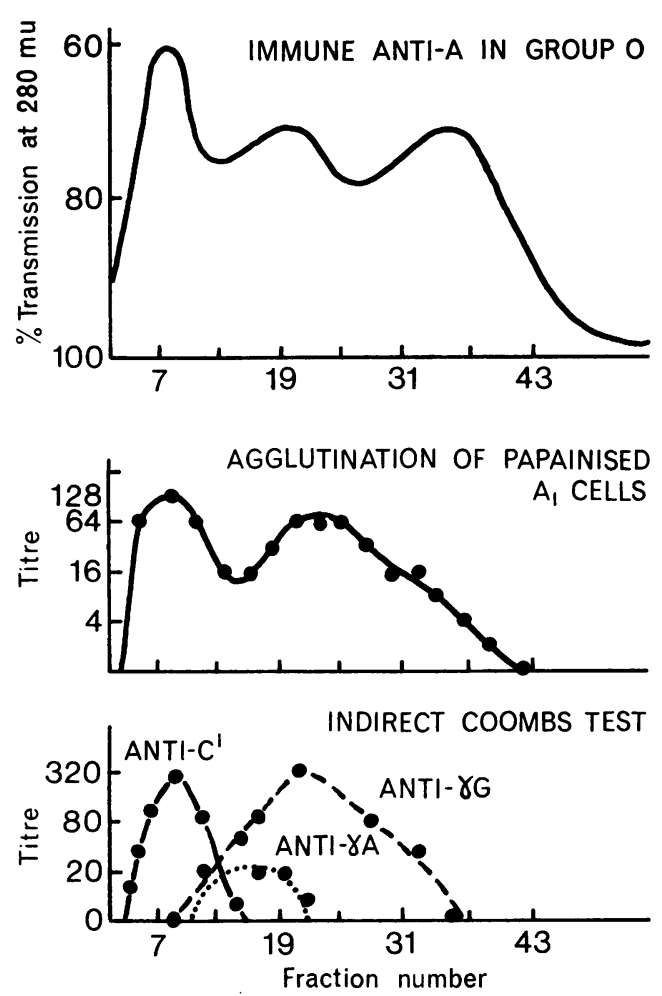

FIG. 3. Gel filtration of group $O$ serum containing immune anti-A, showing position of anti-A immunoglobulins (Mr $G$.).

ANALYSIS OF ANTI-A AND ANTI-B ANTIBODIES Two kinds of anti-A and anti-B antibodies were analysed, those from persons who were group $O$ and those from persons who were group A or B. A typical example of the analysis of a group $O$ serum is shown in Fig. 4, which is of the serum from a mother who gave birth to a group $A$ child affected with $A B O$ haemolytic disease. Using the indirect antiglobulin method, no $\gamma \mathrm{A}$ globulin antibody could be detected in the fractions so the distinction is between $\gamma \mathrm{M}$ and $\gamma \mathrm{G}$ position antibody, and it will be observed that both act as agglutinins in saline and give strongly positive results with papainated cells. Tests with $\mathbf{A}^{\mathbf{p}}$ pig red cells show that agglutination of these cells in saline is confined to the $\gamma \mathrm{M}$ position fractions (confirming the work of Polley, Adinolfi, and Mollison, 1963), and tests with papainated Ax red cells also showed that the agglutination was only found in the $\gamma \mathrm{M}$ position fractions. Titration of the peak tube of the $\gamma \mathrm{G}$ curve can be used as an indication of the strength of $\gamma \mathrm{G}$ antibody in the serum.

There is a considerable difference if a serum from a group A or group B individual is examined; we have usually found that the saline agglutinating
anti-B or anti-A in the $\gamma \mathrm{G}$ position is much reduced. or almost totally absent.

ANALYSIS OF MIXTURES OF ANTIBODIES We have analysed a number of sera where there is more than one atypical antibody present. In antenatal cases i is particularly desirable to know the immunoglobulin
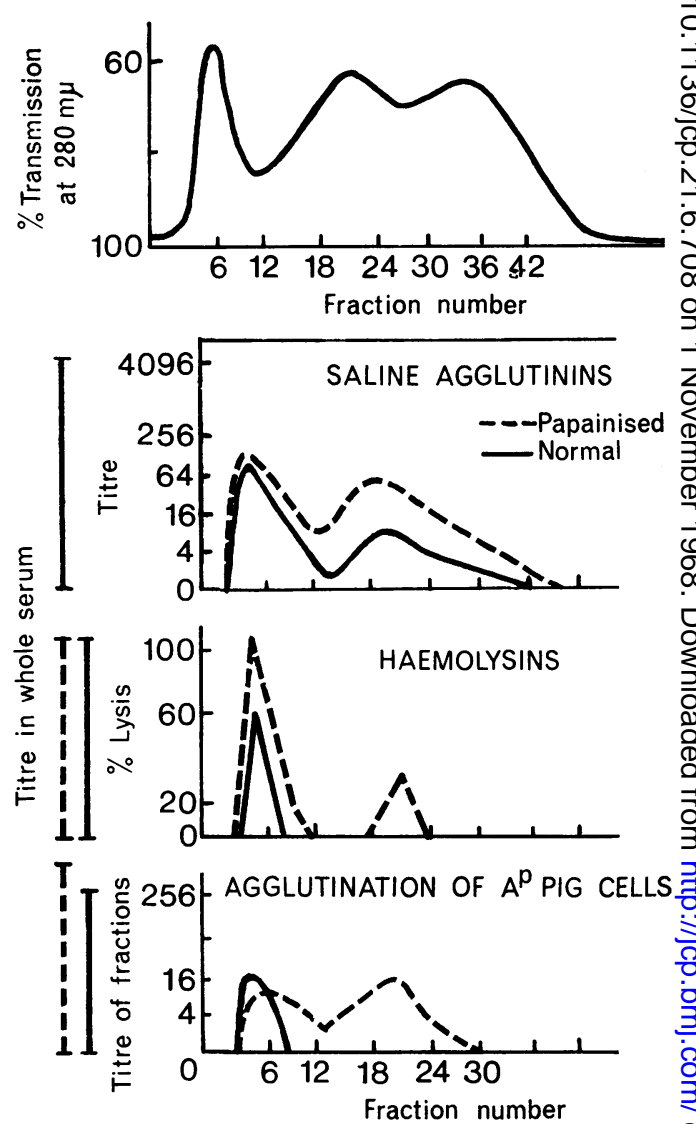

FIG. 4. Gel filtration of group $O$ serum from the mother of a baby with $A B O$ haemolytic disease.

type of the antibodies and two examples are giver to illustrate this work. Figure 5 shows Mrs WN whose serum contained anti-Jk ${ }^{2}$ and anti-c antic body and, as is seen in the figure, the anti-c is a $\gamma \Phi$ position antibody and the anti-Jk ${ }^{\mathrm{a}}$ is $\gamma \mathrm{M}$ position Consequently, the haemolytic disease in this cas would be expected only from the anti-c antibody. $\stackrel{?}{\rightarrow}$

Figure 6 shows the analysis of a serum which contained anti-s and anti-Fya antibody. It will b $\vec{\oplus}$ seen that the anti-s, detectable with the anti-C antiglobulin reagent, occurred in the $\gamma \mathrm{M}$ positio and the anti-Fy ${ }^{a}$ in the $\gamma \mathrm{G}$ position. 

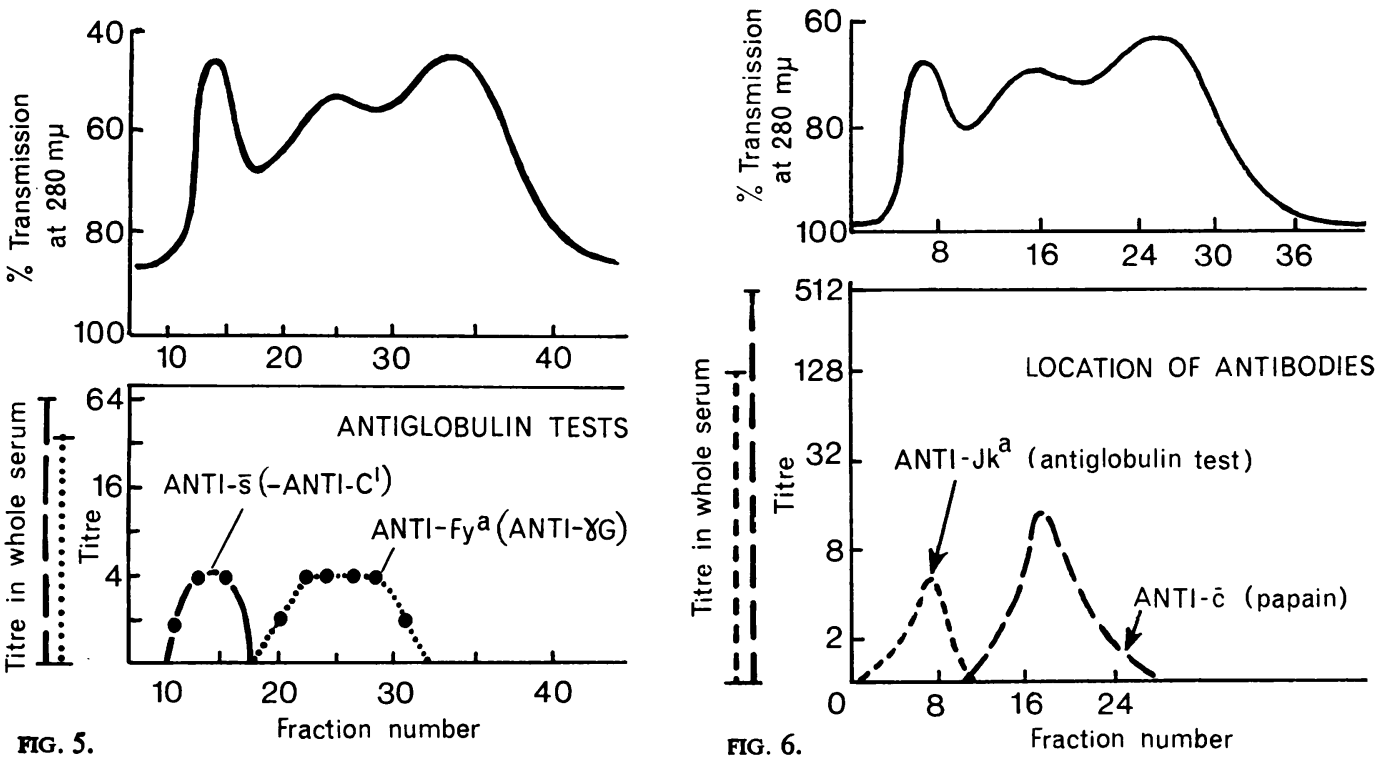

FIG. 5.

Fraction number

FIG. 6.

FIG. 5. Gel filtration of serum containing anti-Jk ${ }^{a}$ and anti-c antibody (Mrs W.).
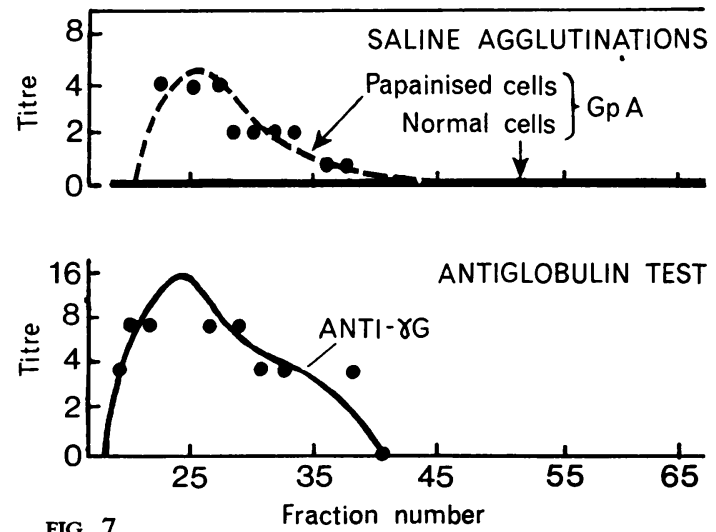

FIG. 6. Gel filtration of serum containing anti-s and anti-Fya.

FIG. 7. Gel filtration of serum containing immune anti-A after treatment with group $A$ specific substance, final concentration 1:80,000. 
Analyses of sera containing, for example, antiLewis antibodies, have shown that they are consistently confined to the $\gamma \mathrm{M}$ peak.

EXPERIMENTAL WORK The study of antibodies in serum is often greatly assisted by gel filtration. For example, in the course of experiments on anti-A present in group $\mathrm{O}$ sera, it was decided to add $\mathbf{A}$ substance to the serum from a mother with immune anti-A, partially to neutralize the antibody. Figure 7 shows the results of this experiment and it can be seen that the $\gamma \mathrm{G}$ antibody has shifted to the $\gamma \mathrm{M}$ position. This is due, presumably, to the combination of $\gamma \mathrm{G}$ anti-A and $\mathrm{A}$ specific polysaccharide to form a large molecule.

\section{DISCUSSION}

Sephadex G-200, a cross-linked dextran gel, can be used to obtain an efficient separation of serum proteins on the basis of differences in molecular size. Human serum separates into three major peaks corresponding to $19 \mathrm{~S}, 7 \mathrm{~S}$, and $4 \mathrm{~S}$ proteins, and using this gel good separations of $19 \mathrm{~S}$ and $7 \mathrm{~S}$ antibodies can be obtained (Fig. 1).

When standard antibodies, anti-I and incomplete anti-D (which are known from other tests to be respectively 19S $\gamma \mathrm{M}$ globulin and 7S $\gamma \mathrm{G}$-globulin), are run through the column and titrated out, the anti-I appears under the first peak and anti-D under the second peak, and the curve obtained on titration of the antibodies follows very closely the protein concentration recording of the effluent. Thus, a correlation is established between a particular antibody and a particular globulin and this association is illustrated by comparing Figures 1 and 2 .

Although Sephadex will distinguish the 19S from $7 \mathrm{~S}$ antibodies it will not, of course, indicate the immunoglobulin nature of the antibody in all its aspects, but our experience has shown that $\gamma \mathrm{M}$ antibodies come out under the first peak and $\gamma \mathrm{G}$ under the second one. A valuable additional method of examination of the effluents is to use an indirect antiglobulin test employing specific reagents, anti- $\gamma \mathrm{M}$, anti- $\gamma \mathrm{A}$, and anti- $\gamma \mathrm{G}$, to test the sensitized cells $\frac{\mathrm{O}}{\circ}$ made using particular fractions from the column $\overrightarrow{\overrightarrow{\mathrm{r}}}$ Schultze and Heremans (1966) have shown thaf whilst most of the $\gamma \mathrm{A}$ globulin in serum is $7 \mathrm{~S}$, smale amounts occur in the form of polymers $10.3 \mathrm{~S}$ anc 13S. In the particular case of $\gamma \mathrm{A}$ antibody, Ishizaka Ishizaka, Lee, and Fudenberg (1965) showed tha although much of it occurred as 7S, the polymeren form had greater agglutinating activity. As Fig. 3 shows, using an indirect antiglobulin test, the occurrence of $\gamma \mathrm{A}$ anti-A can be demonstrated. Infw practice, the problem of $\gamma \mathrm{A}$ antibodies has not yes proved to be a serious one since so far they have not often been encountered.

An indirect antiglobulin test using specific antiserą may not give positive results when they are expecte $\phi_{0}$ and this is particularly so in the reaction betweeno anti- $\gamma \mathrm{M}$ and cells coated with $\gamma \mathrm{M}$ globulin anti $=$ bodies. Rarely, it is difficult to get a positive indirect $z$ antiglobulin test when the antibody is apparentlye a $\gamma \mathrm{G}$ globulin, but an example is shown in Fig. and Table I. Here, the two antibodies are readilyo separated by gel filtration and the anti-c shows maximum activity beneath the $7 \mathrm{~S}$ peak. Nevertheless $\vec{\emptyset}$ the results with anti- $\gamma \mathrm{G}$ reagent using a slide tech 90 nique were negative and weakly positive results were found with this reagent only by using more sensitive techniques. In such a case gel filtration studies ar particularly helpful.

The work illustrated here, and other investigations that have been done, have shown that particularly in an analysis of the sera of group $O$ individuals it is impossible to predict the immunoglobulin type of the anti-A or anti-B activity from a consideration of its serological activity (Fig. 4); this may apply to. other antibodies. The effluents from the column are tested by the method that will detect the antibody? most readily; eg, papainized cell tests or saline agglutination tests are often employed because they? can be quickly and easily done.

Castanedo and Williams (1967) have reported thas the fractions associated with the first peak on Sephadex analysis have anticomplementary prop? erties. We have observed this too, when analysing anti-Lewis antisera and difficulties are encountered

TABLE I

SEROLOGICAL TESTS ON SERUM OF MRS $\mathrm{W}$. CONTAINING ANTI-JK ${ }^{a}$ AND ANTI-c

Test Cells Papain
Slide Te Slide Test

\section{Agglutinins}

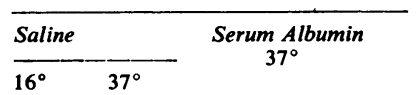

Orr JkJkb

O.R $R_{1} \mathbf{J k}_{\mathbf{l}} \mathrm{Jk}^{\mathrm{b}}$

$O . R_{1} R_{1} J^{b} k^{b}$

$O . R_{1} R_{2} \quad J^{b} J^{b}$

O.rr Jk Jk

$\begin{array}{lllll}+++++ & +++ & + & ++ & - \\ - & - & - & - & - \\ - & - & - & - & - \\ -++++ & +++ & - & ++ & -\end{array}$

Antiglobulin Test

\begin{tabular}{llll}
\hline Anti- & Anti- & Anti- & Anti- \\
$\gamma M$ & $\gamma G$ & $\gamma A$ & $C^{\prime}$
\end{tabular}

$\begin{array}{llll}- & -(+) & - & - \\ - & - & - & ++++ \\ - & - & - & - \\ - & - & - & - \\ - & -(+) & - & ++++\end{array}$


in detecting these antibodies if they are complementfixing and a two-stage test may be necessary. These authors ascribed the anticomplementary properties of the effluent appearing under the first peak as due to particulate mixture which they thought to be aggregates of $\gamma \mathrm{G}$-globulin. In most instances, anticomplementary activity was not found under the 7S peak.

However, Laurell and Siboo (1966) showed that $C^{\prime} 1$ esterase was found in the effluents appearing under the 19S peak, and Stratton and Rawlinson (1965) demonstrated that if, in whole serum, C'1 was separated from its inhibitor, the esterase ( $\left.C^{\prime} l a\right)$ was activated in this state and it could destroy other complement components. Our observations are in accord with those of Laurell and Siboo (1966) and show that active $C^{\prime} 1$ esterase is present in the fractions occurring under the 19S peak on Sephadex analysis of serum; this is one of the causes of the anticomplementary activity shown in some of these fractions and indeed experiments we have undertaken have shown that using these fractions sensitized cells, EA, can be converted to EAC'la.

This may not be the whole explanation of the anticomplementary activity in these fractions, since high speed centrifugation can sometimes reduce the anticomplementary activity, and heating at $56^{\circ} \mathrm{C}$ may not entirely abolish it; such treatment may, of course, be damaging to the antibody in the fraction. The anticomplementary activity of these fractions under the 19S peak should be borne in mind and measures taken to avoid it, particularly when analyses on the column are made of complementfixing blood group antibodies which are thought to be of $\gamma \mathrm{M}$ specificity.

Analyses of the sera of group $O$ mothers, especially those who have given birth to children affected with ABO haemolytic disease, have shown that the $\gamma \mathrm{G}$ anti-A antibody is very strongly active in the second peak. In the analyses of the sera of mothers who are group B, or group A, anti-A or anti-B activity under the $7 \mathrm{~S}$ peak due to $\gamma \mathrm{G}$ antibody has been low or absent. This method may prove to be a useful one for estimating $\gamma \mathbf{G}$ anti-A or anti-B activity in the sera of mothers who might be likely to give birth to children affected with ABO haemolytic disease.

Gel filtration studies are often useful in experimental work. As an example of this we include our observations on the analysis of a group $O$ serum to which group A specific polysaccharides have been added before chromatography. This shows that there is a shift of antibody activity to the left which suggests that $\gamma \mathrm{G}$ anti-A molecules together with bound polysaccharides come out of the column under the $19 \mathrm{~S}$ position. This seems to indicate a promising approach to the study of the binding of anti-A with A polysaccharides and investigations are proceeding further.

We have also found the method particularly useful in the fractionation of antiglobulin sera. These sera often contain antibodies which are active against normal red cells, against infected cells, or against papainized cells, and gel filtration of the antiglobulin serum in the manner described will often separate the unwanted component referred to from the anti-protein component. The former occurs under the 19S peak and the latter under the $7 \mathrm{~S}$ peak. This is a very useful method and will be described more fully elsewhere (Stratton and Rawlinson, to be published), and indeed such fractionation may be essential if sensitive antiglobulin techniques are to be used and, of course, is superior to absorption, in that activity against infected or papainized cells may also be removed by this procedure.

No single method can give all the available information that is required to determine the immunoglobulin type of an antibody. Investigations in our laboratory have included fractionation on DEAE-cellulose, sucrose-density gradient studies and electrophoresis on polyvinyl particle blocks, in addition to treatment of serum and sensitized cells with sulphydryl compounds. All these investigations on different kinds of antibodies have agreed with the information that has been obtained by an analysis of these sera on Sephadex G-200. A typical example of such a complete study has recently been described (Stratton, Smith, and Rawlinson, 1968). Nevertheless, some of these investigations are time consuming and difficult and our conclusions are that Sephadex G-200 analysis of human serum containing blood group antibodies is, in itself, a valuable method to be used in these determinations.

The main advantage of this technique is its simplicity of operation. Using the LKB automatic apparatus, it has been found possible to use a single column repeatedly; furthermore, a buffer can be selected so that very little alteration needs to be made to the fractions before testing them for antibody content, and a serum may be put through the column in a few hours. Our results under these conditions have been very consistent.

\section{REFERENCES}

Abelson, N. M., and Rawson, A. J. (1961). Transfiusion, 1, 116. Adinolf, M., Mollison, P. L., Polley, M., and Rose, J. (1966). J. exp. Med., 123, 951.

Castanedo, J. P., and Williams, R. C. Jr (1967). J. Lab. clin. Med., 69, 217.

Fahey, J. L., and McKelvey, E. M. (1965). J. Immunol., 94, 84.

Ishizaka, K., Ishizaka, T., Lee, E. H., and Fudenberg, H. (1965). Ibid., 95, 197.

Killander, J., and Högman, C. F. (1963). Scand. J. clin. Lab. Invest., 15, suppl. 69, 130. 
Kochwa, S., and Rosenfield, R. E. (1964). J. Immunol., 92, 682.

Laurell, A. B., and Siboo, R. (1966). Acta path. microbiol. scand., 68, 230.

Mehrotra, T. N. (1960). Immunology, 3, 265.

- and Charlwood, P. A. (1960). Ibid., 3, 254.

Polley, M. J., Adinolfi, M., and Mollison, P. L. (1963). Vox Sang (Basel), 8, 385.

Schultze, H. E., and Heremans, J. F. (1966). Molecular Biology of Human Proteins, vol. 1, p. 227. Elsevier, Amsterdam.
Stratton, F., Gunson, H. H., and Rawlinson, V. I. (1962). Transfusion, 2, 135.

(1965). Ibid., 5, 216.

and Rawlinson, V. I. (1965). Brit. J. Haemat., 11, 592.

- To be published.

$\longrightarrow$, and Renton, P. H. (1958). Practical Blood Grouping. Blackwell, Oxford.

-, Smith, D. S., and Rawlinson, V. I. (1968). Clin. exp. Immunol., $\frac{\bar{S}}{\bar{S}}$ 3,81 .

\section{The September 1968 Issue}

\section{THE SEPTEMBER 1968 ISSUE CONTAINS THE FOLLOWING PAPERS}

Biochemical consequences of chronic renal failure: A review M. R. WILLS

Water, sodium, potassium, and chloride content of skeletal muscle in fit and ill subjects C. T. G. FLEAR, IRENÉ FLORENCE, and J. A. WILLIAMS

Binding of neomycin and analogues by fatty acids in vitro R. W. LACEY

Modified colorimetric ultramicro method for estimating Nefa in serum M. C. ELPHICK

Cystinosis: electron microscopic evidence of lysosomal storage of cystine in lymph node A. D. PATRICK and B. D. LAKE

An immunofluorescence method for the diagnosis of primary syphilis using an absorption technique $M$. F. GARNER and J. H. ROBSON

Histochemical investigation of acid mucosubstances in secondary amyloidosis C. A. PENNOCK, J. BURNS, and G. MASSARELLA

Chemical and histochemical characterization of mucopolysaccharides in a jaw myxoma J. J. HODson and R. E. S. PROUT

Coexistence of pernicious anaemia and acute erythraemic myelosis E. M. RIDDELL and R. J. L. DAVIDSON

Determination of vitamin $B_{12}$ absorption by a simple whole body counter N. D. C. FINLAYSON, D. J. C. SHEARMAN, J. D. SIMPSON, and R. H. GIRDWOOD

Prophylactic folic acid in women with pernicious anaemia pregnant after infertility MARION HALL and RONALD J. L. DAVIDSON

Serum iron, total iron-binding capacity, and percentage saturation in normal subjects R. SINNIAH and D. W. NEILL

Intravenous iron-dextran: studies on unsaturated ironbinding capacity J. S. G. COX, G. F. MOSS, I. BREMNER, and JANET REASON

Cytochrome oxidase activity in the gastric mucosa of patients with iron deficiency w. D. STONE
Role of lipoproteins in the formation of spur cell anaemia MANUEL MARTINEZ-MALDONADO

Autoimmune haemolytic anaemia associated with ovarian dermoid cyst L. R. I. BAKER, M. C. BRAIN, J. G. $\varnothing$ AZZOPARDI, and S. M. WORLLEDGE

Horse agglutinins in infectious mononucleosis. III $^{-}$ Criterion for differential diagnosis C. L. LEE, F. ZANDREW $Z$ and I. DAVIDSOHN

Factor VIII and antibody levels in plasma fractions prepared by cryoprecipitation ANDREW POLLOCK

Latex-bound antifibrinogen test for plasma fibrinogen $\vec{\varrho}$ assay D. J. CASTELAN, J. HIRSH, and M. MARTIN

Lipid content of malignant lymphomas D. H. WRIGHT

Survey of the eventual diagnosis in 600 cases referred for a second histological opinion after an initial biopsy diagnosis of Hodgkin's disease w. ST. C. SYMMERS $\mathbb{D}$ SENR.

Survey of the eventual diagnosis in $\mathbf{2 2 6}$ cases referred for a second histological opinion after an initial biopsye diagnosis of reticulum cell sarcoma w. ST. C. SYMMERS? SENR.

Labial salivary gland biopsy in Sjögren's disease D. M CHISHOLM and D. K. MASON

Plasmacytoma of the thyroid J. R. S. MORE, D. wồ DAWSON, A. J. RALSTON, and ISLA CRAIG

\section{Technical methods}

Potentiometric method for the determination of inorganic fluoride in biological material F. W. BARNES and $\mathrm{J}$. RUNCIE

Quick-drying sterile cabinet for culture plates P. N N EDMUNDS

A custom-built hospital blood bank D. G. CHALMERS

Letter to the Editor

Book reviews

Notices

Copies are still available and may be obtained from the PUBLISHING MANAGER BRITISH MEDICAL ASSOCIATION, TAVISTOCK SQUARE. W.C.1, price 18s. 6D. 